\title{
Forecasting of Rice Production in North-East states of India
} Kanchan Dutta

\begin{abstract}
Rice is one of the most important food crops of India in terms of area, production and consumer preference. India is the second largest producer and consumer of rice in the world. Trends in global rice consumption largely follow those in global production, rising steadily over the last few decades. However population growth has outpaced growth in rice production, such that per capita production, and thus per capita consumption is declining. For future planning, it is therefore necessary to evaluate the growth pattern of rice production. An attempt has been taken in this paper to forecast (through Box-Jenkins technique) the production of rice in North-East states of India. The study finds that the respective models for best forecasting of Rice production are ARIMA $(1,1,0)$ for Assam, ARIMA $(1,0,1)$ for Arunachal Pradesh, ARIMA $(1,1,2)$ for Nagaland, and ARIMA $(1,0,0)$ for Sikkim. This study also finds that Forecasting for Mizoram is not possible under the present methodology since the data series is non-stationary and they are not becoming stationary even after second difference. Similarly forecasting of rice production of Tripura and Meghalaya is also not viable. The data series are $\mathrm{I}(1)$, but in the first differenced series there is no significant spike in ACFs, indicating that the first differenced series are white noise. Moreover forecasting indicates possibility of a decline in rice production in most of the states in North East India.
\end{abstract}

Keywords: Rice Production, Forecasting, North East India.

\subsection{Introduction}

Rice is the major staple crop of nearly half of the world's population, and is particularly important in Asia, where approximately $90 \%$ of world's rice is produced and consumed (Zeigler and Barclay, 2008; Khush, 2004). Rice has inelastic demand, and inadequate storage infrastructure in most developing countries including India.

Dr. Kanchan Datta, Associate Professor of Economics, University of North Bengal. 
Thus trends in global rice consumption largely follow those in global production, rising steadily over the last few decades. However population growth has outpaced growth in rice production, such that per capita production, and thus per capita consumption is declining. As demand is highly inelastic, reductions in aggregate production result in large price increases and consumer welfare losses.

Rice is one of the most important food crops of India in term of area, production and consumer preference. India is the second largest producer and consumer of rice in the world. Rice occupies $23 \%$ of the cropped area that represents nearly $30 \%$ of the world's rice area and contributes approximately $42 \%$ of the India's food grain production. (Nivedita, 2000). The agriculture sector of India has been undergoing rapid changes, especially in recent years, as a result of improved technologies, investment in infrastructure and policy support. Introduction of semi-dwarf, high-yielding variety rice in early seventies was mainly responsible for steady increase in rice production over the years which has helped India attain self-sufficiency in food grain production. Rapid gains in productivity achieved during 70's and 80's could not be maintained during 90's and beyond due to various reasons as given by experts in the literature. Some of the important reasons include reduction in public investment in agriculture, lack of output price intervention, unsatisfactory rate of adoption of improved technologies, and large scale imports of certain commodities in post WTO regime (Subbaiah, 2006). Therefore, it is necessary to evaluate the growth pattern of rice production for future planning in this area. An attempt has been taken in this paper to investigate the growth pattern of rice production in North-East states of India. The remaining paper is divided into the following sections. Section II deals with the data and methodology, section III explains the empirical findings, and section IV gives the summary and conclusions.

\subsection{Data and Methodology}

This study was carried out on the basis of rice production data from the period 1980 to 2007 collected from secondary sources (Handbook of Statistics on Indian Economy, Reserve Bank of India). We use the data of 2008 to compare the out sample forecasting. The data was modeled using Autoregressive Integrated Moving Average (ARIMA) stochastic model popularized by Box- 


\section{4 | MANTHAN: Journal of Commerce and Management}

Jenkins (1976). An ARIMA (p, d, q) model is a combination of Autoregressive (AR) which shows that there is a relationship between present and past values, a random value and a Moving Average (MA) model which shows that the present value has something to do with the past residuals. Auto correlation function is a very constructive tool to find out whether a time series is stationary or not which is very important in time series econometrics. Both ACF and PACF are also used to determine auto-regression and moving average orders of the models. The forecasting through Box-Jenkings methodology consists of three steps, namely identification, estimation of parameters, and diagnostic checking. The identification step involves the use of the techniques for determining the value of $\mathrm{p}, \mathrm{d}$, and $\mathrm{q}$. Here, these values are determined by using autocorrelation and partial autocorrelation functions (ACE and PACF). Apart from the graphical methods of using ACF for determining stationarity of a time series, a very popular formal method of determining stationarity is the Augmented Dickey-Fuller (ADF) test. Here, these tests are done for all the time series. The second step is to estimate the parameters of the model. Here, the method of OLS is used for this purpose. The third step is to check whether the chosen model fits the data reasonably well. For this reason, the residuals are examined to find out if they are white noise. To test if residuals are white noise, the ACE of residuals are considered in this study for comprising the forecasting efficiency of stochastic models.

\subsection{Empirical Findings}

Since ARIMA forecasting technique needs stationary series, hence to test the stationarity, we apply ADF and PP Unit Root test. The results of these tests are shown in Table-1.

\subsection{Forecasting of Rice Production in Assam (RPAS)}

Since the production series is I(1), hence our estimating regression equation is

$$
\triangle R P A S_{t}=\alpha_{0}+\alpha_{1} \Delta R P A S_{t-1}+U_{t}---(1)
$$


Table 1: Results of Augmented Dickey Fuller (ADF) Unit Root Test

\begin{tabular}{|l|l|l|l|}
\hline Rice Production States & ADF & Exogenous & Prob. \\
& statistic & & \\
\hline Assam & -1.75 & Constant & 0.39 \\
Assam & -2.43 & Con+ li.trend & 0.36 \\
$\Delta$ Assam & -7.91 & Constant & 0.00 \\
$\Delta$ Assam & -8.28 & Con+ li.trend & 0.00 \\
Arunachal & -2.70 & Constant & 0.08 \\
Arunachal & -4.13 & Con+ li.trend & 0.02 \\
Manipur & -1.43 & Constant & 0.55 \\
Manipur & -4.59 & Con+ li.trend & 0.00 \\
$\Delta$ Manipur & -7.04 & Constant & 0.00 \\
Meghalaya & -0.74 & Constant & 0.81 \\
Meghalaya & -2.49 & Con+ li.trend & 0.33 \\
$\Delta$ Meghalaya & -6.83 & Constant & 0.00 \\
$\Delta$ Meghalaya & -6.98 & Con+ li.trend & 0.00 \\
Mizoram & -1.13 & Constant & 0.68 \\
Mizoram & 0.64 & Con+ li.trend & 0.99 \\
$\Delta$ Mizoram & -0.55 & Constant & 0.86 \\
$\Delta$ Mizoram & -0.86 & Con+ li.trend & 0.93 \\
$\Delta^{2}$ Mizoram & -3.18 & Con+ li.trend & 0.11 \\
$\Delta^{2}$ Mizoram & -1.83 & Constant & 0.35 \\
Nagaland & 0.59 & Constant & 0.98 \\
Nagaland & -4.25 & Con+ li.trend & 0.01 \\
$\Delta$ Nagaland & -6.60 & Constant & 0.00 \\
Tripura & -1.13 & Constant & 0.68 \\
Tripura & -3.64 & Con+ li trend & 0.04 \\
$\Delta$ Tripura & -4.84 & Constant & 0.00 \\
Sikkim & -6.92 & Constant & 0.00 \\
Sikkim & -6.45 & Con+li trend & 0.00 \\
\hline
\end{tabular}


146 | MANTHAN: Journal of Commerce and Management

The results and correlogram of the estimating equation (1) are given below in Table 2 and Figure 1 respectively.

Table 2: Results of regression equation (1)

\begin{tabular}{|l|l|l|l|}
\hline $\begin{array}{l}\text { Estimated } \\
\text { Coefficient }\end{array}$ & S.E & t value & Prob \\
\hline$\alpha_{0}=48.55$ & 53.53 & 0.90 & 0.37 \\
\hline$\alpha_{1}=-0.45$ & 0.18 & -2.47 & $0.02^{*}$ \\
\hline $\begin{array}{l}\mathrm{R}^{2}=0.20 ; \quad \text { Adjusted } \mathrm{R}^{2}=0.17 \\
\text { DW Stat. }=1.84 ; \quad \mathrm{F}=6.12, \quad \text { Prob.(F) }=0.02\end{array}$ \\
\hline
\end{tabular}

*implies statistical significance at $5 \%$ level

Figure 1: Correlogram of the error series of equation (1)

\begin{tabular}{|c|c|c|c|c|c|}
\hline Autocorrelation & Partial Correlation & AC & PAC & Q-Stat & Prob \\
\hline b & 1 & 10.069 & 0.069 & 0.1378 & 0.710 \\
\hline 1 & 101 & 20.105 & 0.100 & 0.4695 & 0.791 \\
\hline 1 & 101 & $3-0.068$ & -0.083 & 0.6170 & 0.893 \\
\hline 10 & 10 & $4-0.063$ & -0.065 & 0.7471 & 0.945 \\
\hline 10 & 11 & $5-0.058$ & -0.034 & 0.8631 & 0.973 \\
\hline 1 口 & 10 & $6-0.204$ & -0.195 & 2.3738 & 0.882 \\
\hline 10 & 10 & $\begin{array}{ccc}7 & -0.141\end{array}$ & -0.125 & 3.1365 & 0.872 \\
\hline 1 & । 口 & $\begin{array}{ll}8 & 0.163\end{array}$ & 0.223 & 4.2054 & 0.838 \\
\hline 1 & 101 & $\begin{array}{ll}9 & 0.153\end{array}$ & 0.145 & 5.2132 & 0.815 \\
\hline । 口। & & $10 \quad 0.243$ & 0.165 & 7.8921 & 0.639 \\
\hline 101 & 101 & $11-0.092$ & -0.164 & 8.3005 & 0.686 \\
\hline 10 & 10 & $12-0.062$ & -0.148 & 8.5025 & 0.745 \\
\hline
\end{tabular}

Since the error series is white noise, hence the regression fits the data well; and there is no moving average part (MA), more over the significant $\mathrm{F}$ value also reflects the overall significance of the regression equation. Therefore our estimated ARIMA $(1,1,0)$ forecasting equation becomes,

$$
\begin{aligned}
& R P A S_{t}-R P A S_{t-1}=48.55-0.45\left[R P A S_{t-1}-R P A S_{t-2}\right] \\
& R P A S_{t}=0.55 R P A S_{t-1}+0.45 R P A S_{t-2} \\
& R P A S_{2008}=0.55 R P A S_{2007}+0.45 R P A S_{2006}=3137.65 \\
& R P A S_{2009}=0.55 R P A S_{2008}+0.45 R P A S_{2007}=3697.55 \\
& R P A S_{2010}=0.55 R P A S_{2009}+0.45 R P A S_{2008}=3902.08 \\
& R P A S_{2011}=0.55 R P A S_{2010}+0.45 R P A S_{2009}=4330.4---(2)
\end{aligned}
$$


Therefore the out sample prediction of Rice production in Assam in 2008 is 3186.2 (thousand tons), ignoring the intercept term since it is statistically insignificant whereas the actual value is 4008.5. Similarly, the other values (out sample forecasting) are shown in the Table 3. Figure 2 shows the time plot of Actual and Predicted value of Rice production (in sample).

Table 3: Actual Value, Fitted Value of Rice Production in Assam

\begin{tabular}{|l|l|l|}
\hline Year & Actual Value & Predicted value \\
\hline 2008 & 4008 & 3137 \\
\hline 2009 & 3815 & 3697 \\
\hline 2010 & 4752 & 3903 \\
\hline 2011 & 4009 & 4330 \\
\hline
\end{tabular}

Figure 2: Time plots of Actual, Predicted and forecast error of rice production in Assam

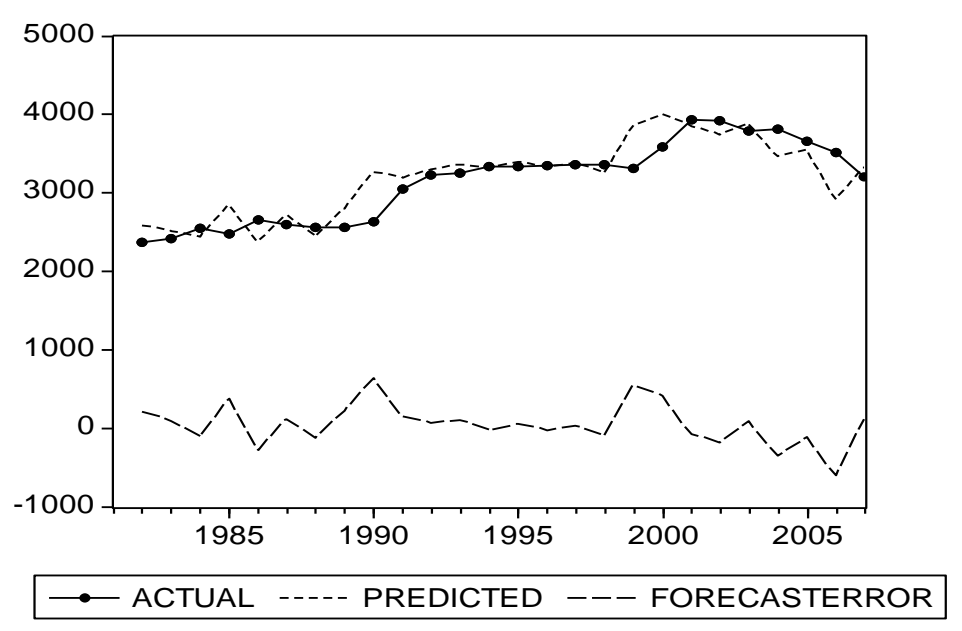


From the above diagram, it is clear that from 1980 to 1988 there was some fluctuation in actual production, which is not well captured by our prediction, but after 1991 to 1999 the rice production was stable, which is well captured by ARIMA $(1,1,0)$. After 2002, the production declined. The figure in the right panel shows the forecast error line, which also reflects that forecasting error is huge specially in 1988, 1997 and 2006. (The reasons of this error are not investigated in this study.)

\subsection{Forecasting of Rice Production in Arunachal Pradesh:}

Since the production series of Arunachal Pradesh is $\mathrm{I}(0)$, hence our estimating regression equation is

$$
R P A R_{t}=\alpha_{0}+\alpha_{1} R P A R_{t-1}+U_{t}---(3)
$$

The results and correlogram of the estimating equation (3) are given below in Table 4 and Figure 3 respectively.

Table 4: Results of regression equation (3)

\begin{tabular}{|l|l|l|l|}
\hline $\begin{array}{l}\text { Estimated } \\
\text { Coefficient }\end{array}$ & S.E & t value & Prob \\
\hline$\alpha_{0}=52.48$ & 18.60 & 2.82 & $0.00^{*}$ \\
\hline$\alpha_{1}=0.61$ & 0.14 & 4.24 & $0.00^{*}$ \\
\hline $\begin{array}{l}\mathrm{R}^{2}=0.42 ; \quad \text { Adjusted } \mathrm{R}^{2}=0.39 \\
\text { DW Stat. }=2.64 ; \quad \mathrm{F}=17.98 ; \quad \text { Prob. }(\mathrm{F})=0.00\end{array}$ \\
\hline
\end{tabular}

* implies statistical significance at 5\% level

Figure 3: Correlogram of the error series of equation (3)

\begin{tabular}{|c|c|c|c|c|c|}
\hline Autocorrelation & Partial Correlation & $\mathrm{AC}$ & PAC & Q-Stat & Prob \\
\hline 1 & ᄃ & $1-0.371$ & -0.371 & 4.1394 & 0.042 \\
\hline 1 & 1 & 20.215 & 0.090 & 5.5827 & 0.061 \\
\hline 1 & 1 & $\begin{array}{ll}3 & 0.028\end{array}$ & 0.156 & 5.6084 & 0.132 \\
\hline 1 & 巨 & $4 \quad 0.075$ & 0.135 & 5.8021 & 0.214 \\
\hline 15 & 1 1 & $5-0.174$ & -0.175 & 6.8839 & 0.229 \\
\hline 1 & 12 & 6 0.259 & 0.126 & 9.3857 & 0.153 \\
\hline 10 & 1[ & $7-0.224$ & -0.070 & 11.355 & 0.124 \\
\hline 17 & 10 & $8-0.022$ & -0.185 & 11.374 & 0.181 \\
\hline 1 吕 & ） & $9-0.158$ & -0.267 & 12.461 & 0.189 \\
\hline 171 & 1 & $10 \quad 0.114$ & 0.040 & 13.056 & 0.221 \\
\hline 1 1 1 & 51 & $11-0.166$ & 0.061 & 14.413 & 0.211 \\
\hline ।曰 & 巨 & $12 \quad 0.236$ & 0.222 & 17.328 & 0.138 \\
\hline
\end{tabular}


The correlogram of the error series of equation (3) shows lag 1 is significant. Hence it implies MA (1) is appropriate for ARIMA model.

Therefore the moving average equation is:

$\mu_{t}=\alpha_{1} \mu_{t-1}+\xi_{t}$

The results of estimation of equation (4) are given in Table 5.

Table-5 Results of regression of equation-4

\begin{tabular}{|l|l|l|l|}
\hline $\begin{array}{l}\text { Estimated } \\
\text { Coefficient }\end{array}$ & S.E & t value & Prob \\
\hline$\alpha_{0}=0.21$ & 2.32 & 0.09 & 0.92 \\
\hline$\alpha_{1}=-0.39$ & 0.19 & -2.07 & $0.04 *$ \\
\hline
\end{tabular}

*implies statistical significance at $5 \%$ level

Since $\alpha_{1}$ is significant, hence our ARIMA $(1,0,1)$ model for forecasting of rice production in Arunachal Pradesh is:

$R P A R_{t}=\alpha_{0}+\alpha_{1} R P A R_{t-1}+\alpha_{2} u_{t-1}+v_{t}---(5)$

The results of estimation is of equation (5) are shown below in Table 6.

Table 6: Estimation results of equation (5)

\begin{tabular}{|l|l|l|l|}
\hline $\begin{array}{l}\text { Estimated } \\
\text { Coefficient }\end{array}$ & S.E & t value & Prob \\
\hline$\alpha_{0}=9.21$ & 28.29 & 0.32 & 0.74 \\
\hline$\alpha_{1}=0.94$ & 0.21 & 4.35 & $0.00^{*}$ \\
\hline$\alpha_{2}=0.71 \quad 0.27$ & 2.57 & 0.01 \\
\hline $\begin{array}{l}\mathrm{R}^{2}=0.46 ; \quad \text { Adjusted } \mathrm{R}^{2}=0.41 \\
\text { DW Stat. = 2.09; } \quad \mathrm{F}=9.9, \text { Prob. }(\mathrm{F})=0.00\end{array}$ \\
\hline
\end{tabular}

*implies statistical significance at $5 \%$ level

The correlogram of the error series of equation (5) is white noise ( Figure 4). 
150 | MANTHAN: Journal of Commerce and Management

Figure 4: Correlogram of the error series of equation (5)

\begin{tabular}{|c|c|c|c|c|c|}
\hline Autocorrelation & Partial Correlation & $\mathrm{AC}$ & PAC & Q-Stat & Prob \\
\hline 1 & 1 & $1-0.097$ & -0.097 & 0.2745 & 0.600 \\
\hline 1 & 1 & $2-0.071$ & -0.081 & 0.4254 & 0.808 \\
\hline 口 & 口 & 30.212 & 0.200 & 1.8456 & 0.605 \\
\hline 1 & 1 & $4-0.009$ & 0.027 & 1.8483 & 0.764 \\
\hline 10 & 15 & $5-0.132$ & -0.110 & 2.4516 & 0.784 \\
\hline & । 口 । & $6 \quad 0.239$ & 0.188 & 4.5223 & 0.606 \\
\hline 1 प 1 & 101 & $\begin{array}{ll}7 & -0.129\end{array}$ & -0.121 & 5.1582 & 0.641 \\
\hline $1 \square$ & $1 \square$ & $8-0.280$ & -0.261 & 8.3302 & 0.402 \\
\hline 14 & $\square$ & $9-0.147$ & -0.321 & 9.2539 & 0.414 \\
\hline 1 & 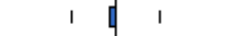 & $10 \quad 0.005$ & -0.057 & 9.2549 & 0.508 \\
\hline 1 1 & 1 & $11-0.141$ & -0.032 & 10.221 & 0.511 \\
\hline । 口 । & 曰 । & $12 \quad 0.172$ & 0.235 & 11.759 & 0.465 \\
\hline
\end{tabular}

Therefore our estimated ARIMA $(1,0,1)$ forecasting equation becomes:

$$
\begin{aligned}
& R_{P A R_{t}}=9.21+0.94 R P A R_{t-1}-0.39 \mu_{t-1} \\
& R P A R_{2008}=9.21+0.94 R P A R_{2007}-0.39 \mu_{2007} \\
& R P A R_{2009}=9.21+0.94 R P A R_{2008}-0.39 \mu_{2008}
\end{aligned}
$$

Out sample forecast of rice production in Arunachal Pradesh is 156.08 thousand tons in 2008 whereas the actual value is 163.9.

Figure 5 gives time plots of Actual, Predicted and forecast error of rice production in Arunachal Pradesh.

Figure 5: Time plots of Actual, Predicted and forecast error of rice production in Arunachal Pradesh

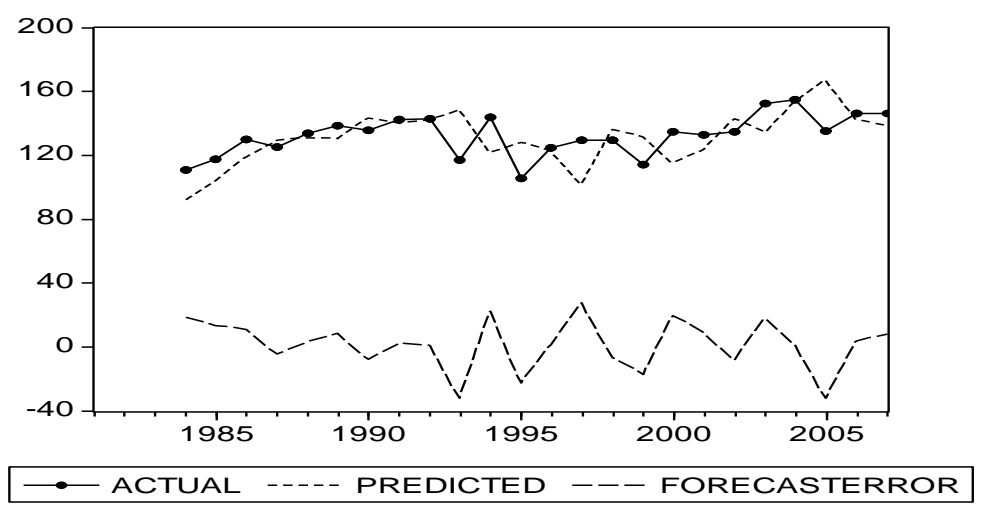




\subsection{Forecasting of Rice production in Nagaland}

Since the production series of rice in Nagaland is I(1), hence our estimating regression equation is

$\triangle R P N A_{t}=\alpha_{0}+\alpha_{1} \Delta R P N A_{t-1}+U_{t}---(6)$

The results of estimation of equation (6) and the correlogram of the error series are given in Table 7 and Figure 6 respectively.

Table 7: Estimation results of equation (6)

\begin{tabular}{|c|c|c|c|}
\hline $\begin{array}{l}\text { Estimated } \\
\text { Coefficient }\end{array}$ & S.E & t value & Prob \\
\hline$\alpha_{0}=10.35$ & 5.45 & 1.89 & $0.06 * *$ \\
\hline$\alpha_{1}=-0.45$ & 0.18 & -2.45 & $0.02 *$ \\
\hline \multicolumn{4}{|c|}{$\begin{array}{l}\mathrm{R}^{2}=0.19 ; \quad \text { Adjusted } \mathrm{R}^{2}=0.16 \\
\text { DW Stat. }=2.40 ; \quad \mathrm{F}=5.98, \quad \text { Prob. }(\mathrm{F})=0.00\end{array}$} \\
\hline
\end{tabular}

Figure 6: Correlogram of the error series of equation (6)

\begin{tabular}{|c|c|c|c|c|c|c|c|c|}
\hline \multicolumn{2}{|c|}{ Autocorrelation } & \multicolumn{2}{|c|}{ Partial Correlation } & \multicolumn{2}{|r|}{$\mathrm{AC}$} & PAC & Q-Stat & Prob \\
\hline $1 \sqsubset$ & 1 & 1 & 1 & 1 & -0.209 & -0.209 & 1.2741 & 0.259 \\
\hline $1 \square$ & 1 & I & I & 2 & -0.289 & -0.348 & 3.8004 & 0.150 \\
\hline 1 & 7 & 1 & 1 & 3 & 0.360 & 0.245 & 7.9000 & 0.048 \\
\hline 1 & 1 & 1 & 1 & 4 & -0.129 & -0.110 & 8.4484 & 0.076 \\
\hline 1 & 1 & 1 & I & 5 & -0.171 & -0.051 & 9.4585 & 0.092 \\
\hline I & 1 & I [ & 1 & 6 & -0.045 & -0.299 & 9.5324 & 0.146 \\
\hline 1 & 1 & 1 & 1 & 7 & -0.074 & -0.173 & 9.7441 & 0.204 \\
\hline 1 & 1 & I & 1 & 8 & -0.052 & -0.205 & 9.8530 & 0.275 \\
\hline 1 & I & I & I & 9 & 0.105 & 0.089 & 10.322 & 0.325 \\
\hline 1 & I & 1 & 1 & 10 & -0.035 & -0.087 & 10.379 & 0.408 \\
\hline 1 & 1 & 1 & I & 11 & -0.067 & -0.092 & 10.595 & 0.478 \\
\hline 1 & 1 & 1 & 1 & 12 & 0.209 & -0.007 & 12.873 & 0.378 \\
\hline
\end{tabular}

From the correlogram of the error series it is clear that lag 2 is significant, which implies MA (2) may be appropriate in our ARIMA model forecasting. Therefore our ARIMA $(1,1,2)$ model of forecasting of rice production in Nagaland becomes:

$\Delta R P N A_{t}=\alpha_{0}+\alpha_{1} \Delta R P N A_{t-1}+\alpha_{2} \mu_{t-2}+v_{t}--(7)$ 
The results of estimation of equation (7) and the correlogram of the error series are given in Table 8 and Figure 7 respectively.

Table 8: Estimation results of equation (7)

\begin{tabular}{|l|l|l|l|}
\hline $\begin{array}{l}\text { Estimated } \\
\text { Coefficient }\end{array}$ & S.E & t value & Prob \\
\hline$\alpha_{0}=12.52$ & 5.60 & 2.23 & $0.04^{*}$ \\
\hline$\alpha_{1}=-0.68$ & 0.22 & -3.05 & $0.00^{*}$ \\
\hline$\alpha_{2}=0.45$ & 0.25 & -1.78 & $0.08^{* *}$ \\
\hline $\begin{array}{l}\mathrm{R}^{2}=0.31 ; \quad \text { Adjusted } \mathrm{R}^{2}=0.24 \\
\text { DW Stat. = 1.97; F }=4.66, \quad \text { Prob.(F) }=0.02\end{array}$ \\
* and ** imply statistical significance at 5\% and 10\% level respectively
\end{tabular}

Figure 7: Correlogram of the error series of equation (7)

\begin{tabular}{|c|c|c|c|c|c|c|c|c|}
\hline \multicolumn{2}{|c|}{ Autocorrelation } & \multicolumn{2}{|c|}{ Partial Correlation } & \multicolumn{2}{|r|}{$\mathrm{AC}$} & PAC & Q-Stat & Prob \\
\hline 1 & 1 & 1 & 1 & & 10.001 & 0.001 & 3.E-05 & 0.996 \\
\hline 1 & 1 & I & 1 & & $2-0.032$ & -0.032 & 0.0292 & 0.986 \\
\hline 1 & 1 & I & I & & $\begin{array}{lll}3 & 0.192\end{array}$ & 0.192 & 1.1203 & 0.772 \\
\hline $1 \square$ & 1 & । & 1 & & $4-0.313$ & -0.328 & 4.1766 & 0.383 \\
\hline 18 & 1 & 1 只 & 1 & & $5-0.160$ & -0.144 & 5.0211 & 0.413 \\
\hline 1 口 & 1 & $1 \square$ & 1 & & $6-0.172$ & -0.260 & 6.0424 & 0.418 \\
\hline 1 든 & 1 & 12 & 1 & & $7-0.162$ & -0.061 & 7.0025 & 0.429 \\
\hline 10 & 1 & 1 口 & 1 & & $8-0.108$ & -0.222 & 7.4608 & 0.488 \\
\hline 1 & 1 & 1 & 1 & & 90.064 & 0.036 & 7.6289 & 0.572 \\
\hline 1 & 1 & 1 & 1 & 1 & $0 \quad 0.063$ & -0.114 & 7.8038 & 0.648 \\
\hline 1 & 1 & 1 & 1 & 1 & 10.047 & -0.026 & 7.9093 & 0.721 \\
\hline 1 & 1 & 1 & 1 & 1. & $\begin{array}{ll}2 & 0.251\end{array}$ & 0.061 & 11.189 & 0.513 \\
\hline
\end{tabular}

The correlogram structure of the error series shows white noise. So the estimation is reliable. Therefore our estimated ARIMA (1,1,2) forecasting equation for rice production in Nagaland becomes,

$\Delta R P N A_{t}=12.52-0.68 \Delta R P N A_{t-1}-0.45 \mu_{t-2}$
$R P N A_{t}-R P N A_{t-1}=12.52-0.68\left(R P N A_{t-1}-R P N A_{t-2}\right)-0.45 \mu_{t-2}$
$R P N A_{t}=12.52+0.32 R P N A_{t-1}+0.68 R P N A_{t-2}-0.45 \mu_{t-2}$
$R P A R_{2008}=12.52+0.32 R P A R_{2007}+0.68 R P N A_{2006}-0.45 \mu_{2006}$


The out of sample forecasting is 279.56 thousand tons of rice in Nagaland for the year 2008 whereas the actual value is 345.1 thousand tons. The time plot of actual, predicted and the residual series is shown in the Figure 8 below.

\section{Figure 8: Time plots of Actual, Predicted and forecast error of rice production in Nagaland}

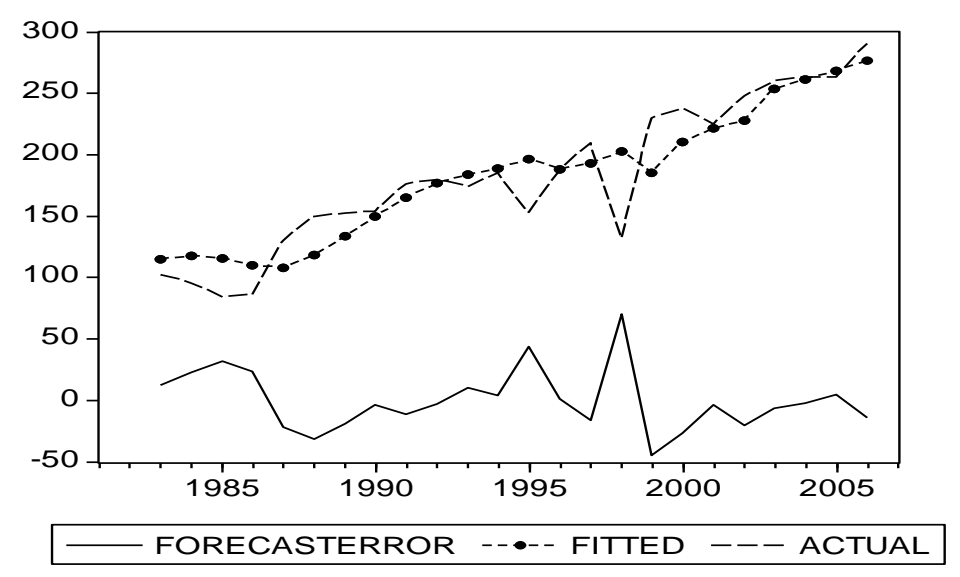

\subsection{Forecasting of Rice production in Sikkim:}

Since the production series of Sikkim is $\mathrm{I}(0)$, hence our estimating regression equation is

$$
\operatorname{RPSK}_{t}=\alpha_{0}+\alpha_{1} \operatorname{RPSK}_{t-1}+U_{t}---(8)
$$

The results of estimation of equation (8) and the correlogram of the error series are given in Table 9 and Figure 9 respectively.

Table 9: Estimation results of equation (8)

\begin{tabular}{|l|l|l|l|}
\hline $\begin{array}{l}\text { Estimated } \\
\text { Coefficient }\end{array}$ & S.E & t value & Prob \\
\hline$\alpha_{0}=4.21$ & 1.60 & 2.82 & $0.01^{*}$ \\
\hline$\alpha_{1}=-0.80 \quad 0.07$ & 10.22 & $0.00^{*}$ \\
\hline $\begin{array}{l}\mathrm{R}^{2}=0.81 ; \quad \text { Adjusted } \mathrm{R}^{2}=0.80 \\
\text { DW Stat. = } 1.91 ; \quad \mathrm{F}=104, \quad \text { Prob. }(\mathrm{F})=0.00\end{array}$ \\
*implies statistical significance at 5\% level
\end{tabular}


154 | MANTHAN: Journal of Commerce and Management

Figure 9: Correlogram of the error series of equation (8)

\begin{tabular}{|c|c|c|c|c|c|c|c|}
\hline \multicolumn{2}{|c|}{ Autocorrelation } & \multicolumn{2}{|c|}{ Partial Correlation } & \multirow{2}{*}{$\frac{A C}{1-0.037}$} & \multirow{2}{*}{$\begin{array}{c}\text { PAC } \\
-0.037\end{array}$} & \multirow{2}{*}{$\begin{array}{c}\text { Q-Stat } \\
0.0401\end{array}$} & \multirow{2}{*}{$\begin{array}{l}\text { Prob } \\
0.841\end{array}$} \\
\hline 1 & 1 & 11 & 1 & & & & \\
\hline & 1 & & 1 & $2-0.275$ & -0.277 & 2.3415 & 0.310 \\
\hline 1 & 1 & 1 & 1 & $3-0.015$ & -0.041 & 2.3482 & 0.503 \\
\hline 1 & 1 & 11 & 1 & $4-0.153$ & -0.253 & 3.1247 & 0.537 \\
\hline 1 & 1 & 1 & 1 & $5-0.037$ & -0.090 & 3.1721 & 0.673 \\
\hline 1 & 1 & 1 & 1 & $\begin{array}{ll}6 & 0.243\end{array}$ & 0.128 & 5.3261 & 0.503 \\
\hline$\square$ & 1 & & 1 & $\begin{array}{lll}7 & -0.392\end{array}$ & -0.495 & 11.224 & 0.129 \\
\hline 다 & 1 & 돈 & 1 & $8-0.127$ & -0.140 & 11.878 & 0.157 \\
\hline 1 & ال & 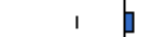 & 1 & 90.338 & 0.081 & 16.776 & 0.052 \\
\hline 1 & 1 & 1 & 1 & $10 \quad 0.037$ & -0.063 & 16.839 & 0.078 \\
\hline 1 & 1 & 1 & 1 & $11-0.036$ & -0.089 & 16.902 & 0.111 \\
\hline 1 & 1 & 1 & 1 & 120.113 & 0.004 & 17.570 & 0.129 \\
\hline
\end{tabular}

The correlogram of the error series shows that ACFs is not significant at any lag. Hence the MA is zero. Therefore our ARIMA model for Sikkim's production is $\operatorname{ARIMA}(1,0,0)$.

On the basis of time plot of actual, predicted and error series (in sample Forecasting) of Rice production in Sikkim (Figure 10), the out of sample forecasting of production in 2008 is 22.53 thousand tons, whereas the actual value is 21.7 .

Figure 10: Time plots of Actual, Predicted and forecast error of rice production in Sikkim

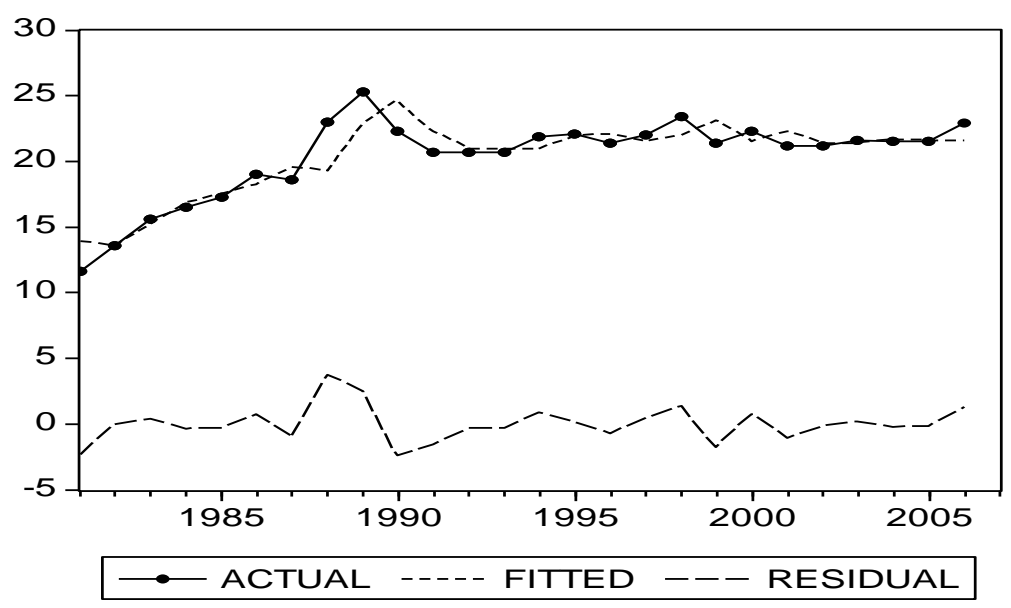


Forecasting of rice production for Mizoram is not possible under the present methodology since the data series is non-stationary and they are not becoming stationary even after second difference. Similarly forecasting of rice production of Tripura and Meghalaya is also not possible, since the data series are I(1), but in the first differenced series there is no significant spike in ACFs, that is, first differenced series are white noise.

\subsection{Summary and Conclusion}

Rice is one of the most important food crops of India in term of area, production and consumer preference. India is the second largest producer and consumer of rice in the world. Trends in global rice consumption largely follow those in global production, rising steadily over the last few decades. However population growth has outpaced growth in rice production, such that per capita production, and thus per capita consumption is declining. For future planning, it is, therefore, necessary to evaluate the growth pattern of rice production. An attempt has been taken in this paper to forecast (through Box-Jenkins technique) the production of rice in North-East states of India. The study finds that the respective models for best forecasting of rice production are ARIMA $(1,1,0)$ for Assam, ARIMA $(1,0,1)$ for Arunachal Pradesh, ARIMA $(1,1,2)$ for Nagaland, and $\operatorname{ARIMA}(1,0,0)$ for Sikkim. This study also finds that forecasting for Mizoram is not possible under the present methodology since the data series is non-stationary and they are not becoming stationary even after second difference. Similarly forecasting of rice production of Tripura and Meghalaya is also not viable, since the data series are I(1), but in the first differenced series there is no significant spike in ACFs indicating that the first differenced series are white noise. Moreover forecasting indicates a declining possibility in rice production in most of the states in North East India.

\section{References}

Awal, M.A \& Siddique, M.A.B. (2011). Rice production in Bangladesh employing by ARIMA model. Bangladesh Journal of Agricultural Research, 36(1): 51-62. 
156 | MANTHAN: Journal of Commerce and Management

Bouis, H. (1991). Rice in Asia: Is it becoming a commercial good? American Journal of Agricultural economics, 73(2): 522-527.

Box, G. E. P., \& Jenkins, G. M. (1976). Time Series Analysis, Forecasting and Control. San Francisco, Holden- Day, California, USA.

Falak, S., \& Eatzaz, A. (2008). Forecasting wheat production in Pakistan. The Lahore Journal of Economics. 3(1): 57-85.

Gujarati, D. N. (2003). Basic Econometrics. Fourth Edition, MeGraw-Hill Inc., New York.

Khush, G.S. (2004). Harnessing science and technology for sustainable rice based production system. Paper presented at the Conference on Rice in Global Markets and Sustainable Production Systems, February 12-13, 2004: Rome (Italy): Food and Agriculture Organization of the United Nations

Zeigler, R.S. \& Barclay, A. (2008). The Relevance of Rice. Rice, 1(1): 3-10. 


\section{Appendix: Some basic statistics of Rice Production in North East States of India}
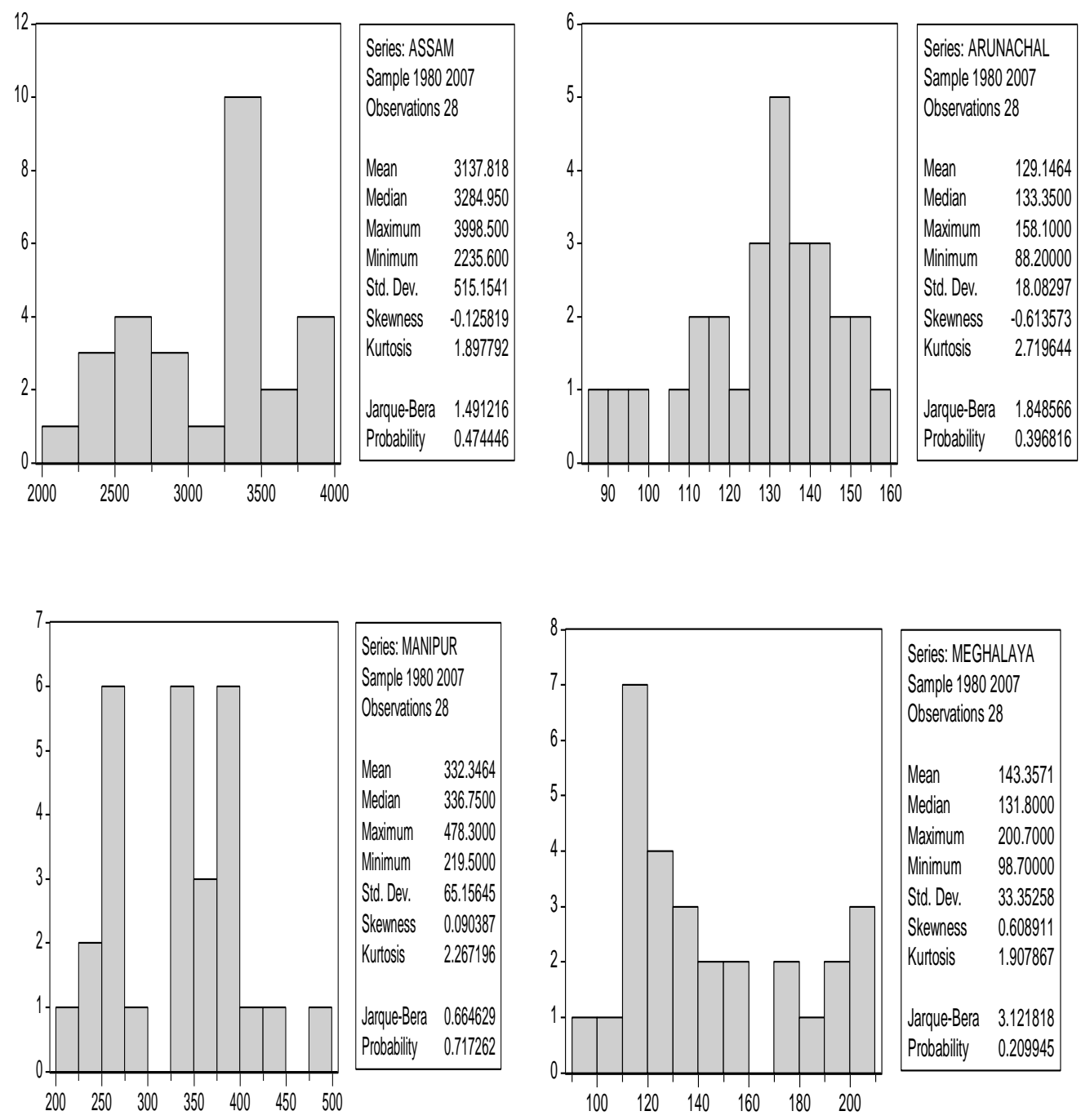
158 | MANTHAN: Journal of Commerce and Management
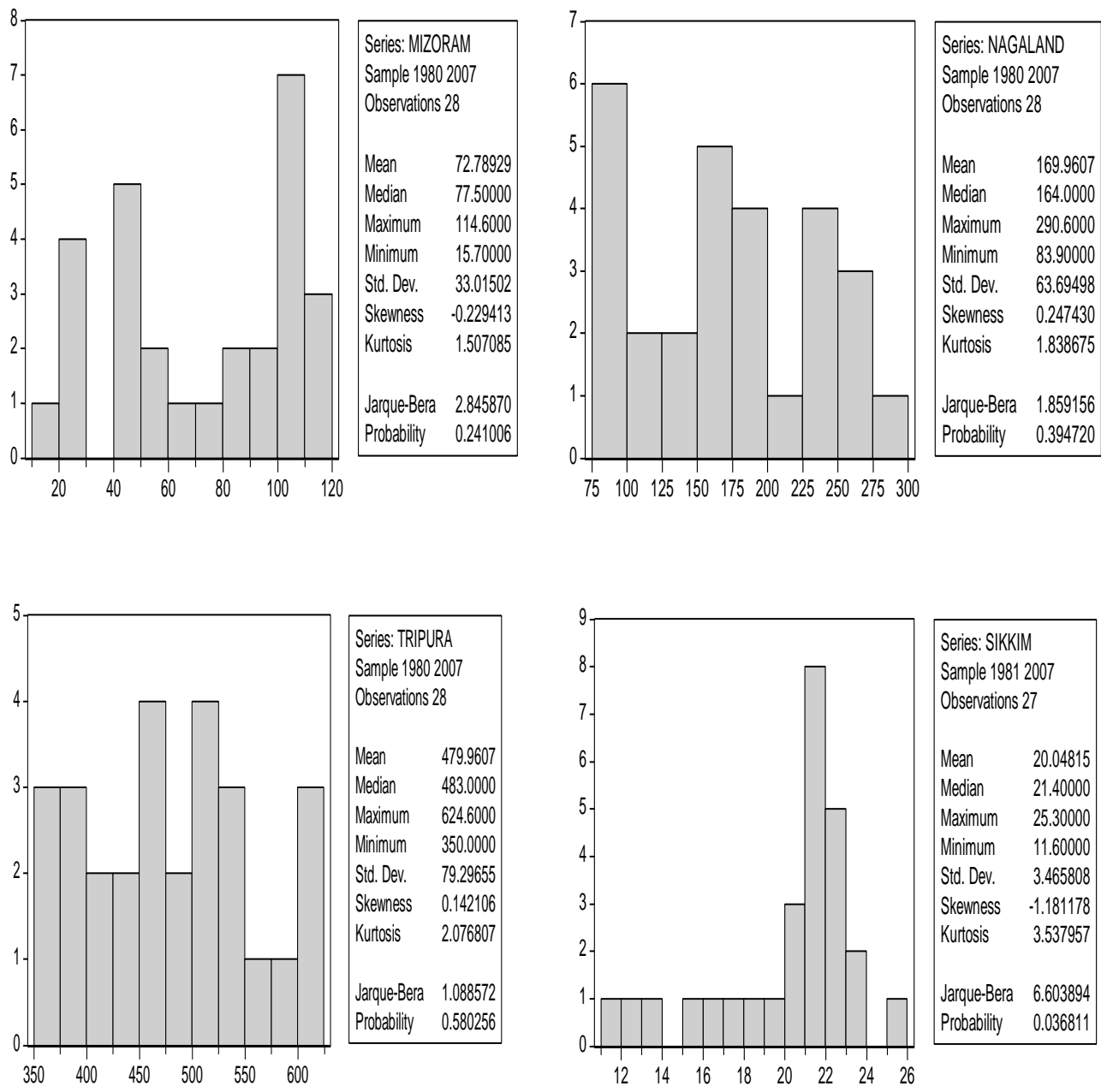